\title{
Between the river and the road: Design and territory in Abaetetuba/Pará/Brazil
}

\author{
Ninon Rose Jardim ${ }^{1, \text { a }}$, Amanda Caren Borges ${ }^{2}$, Bianca Maise Camino ${ }^{3}$, Camilla Dandara Leite ${ }^{4}$ \\ Karolina Norat de Lima ${ }^{5}$, Lauro Arthur Cohen ${ }^{6}$ and Paulo Juan Valente ${ }^{7}$ \\ ${ }^{1}$ State University of Pará, Department of Design, ninonjardim@gmail.com, Brazil \\ ${ }^{2}$ State University of Pará, Department of Design, amanda carendc@yahoo.com.br, Brazil \\ ${ }^{3}$ State University of Pará, Department of Design, bcamino95@gmail.com, Brazil \\ ${ }^{4}$ State University of Pará, Department of Design, dandaraleite3@gmail.com, Brazil \\ ${ }^{5}$ State University of Pará, Department of Design, karolnoratlima@gmail.com, Brazil \\ ${ }^{6}$ State University of Pará, Department of Design, laurocohen@hotmail.com, Brazil \\ ${ }^{7}$ State University of Pará, Department of Design, paulo.sphd@gmail.com, Brazil
}

\begin{abstract}
This work presents the actions of the extension project GOTAS from the State University of Pará (UEPA). The project aims develop the territory through design productions, making partnerships with artisans' associations. In this edition, together with the group Miritong, a furniture collection was developed. The project was based on the methodologies of Lucy Niemeyer and Lia Krucken and created great value academically and socially, proving once more the importance of Design to society.
\end{abstract}

Keywords: Design, Handicrafts, Miriti, Rio, Rua

\section{Contextualizing the territory}

Located at the sides of the Maratauíra river, Abaetetuba is a town in the northeast of Pará state, in Brazil. It is formed by two districts: Abaetetuba district, where the city is based, and Beja district. A group of 72 islands, which marks the place's rural area, surrounds the city.

Abaetetuba is a word from the Tupi language. It is composed by the following terms: $a b a$ (that means man), ete (that means strong/truthful) and tuba (that means place with plenty). Therefore, the word could be translated as "place of strong and truthful men/women".

The cultural aspect is strong in the town. It is noticed by the local handicrafts and use of the region's natural resources, by the music production, by the sugar mills that used to contribute to a prosper brandy industry, by the religious festivities and so on.

The economic prevailing activities are towards the trade, industry and service provision sectors, followed by transformation industry and farming. The Mauritia fluxuosa L. is known as miriti or buriti in Brazil. It is used mainly as food and for handicraft purposes in Abaetetuba and has a high cultural and commercial value at the location.

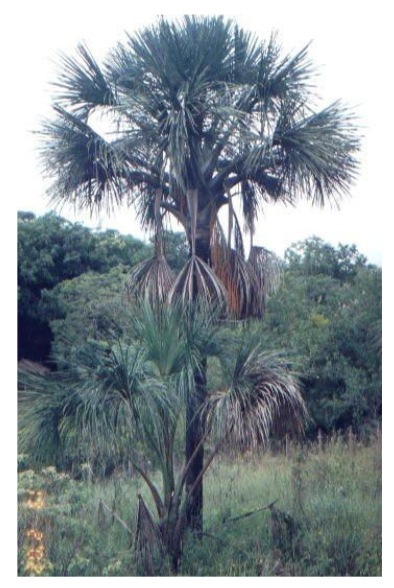

Figure 1: Mauritia Flexuosa L.

Source: http://www.arvores.brasil.nom.br/cerrd/buriti.htm

Although the names miriti and buriti normally refer to the same plant, it is important to mention that some authors consider them distinct palm trees. According to Pesce (1941), there are two species of Mauritia: $M$. flexuosa, called miriti, that grows in the islands and low lands; and $M$. vinifera, which prefers dry and high lands, and is known by the name buriti. 
Pesce (1941) also mentions that they are nearly identical, however the miriti grows higher than the buruti and its fruits are bigger.

It is a sturdy, lone and native palm tree from Amazon, and is also one of the tallest trees - it can grow between 30 to 50 meters high. Alongside with the açaí palm tree, is one of the most typical trees from the region. Yet, it can also be found naturally in other locations at the north of South America (CAVALCANTE, 1996).

Besides being an abundant species, it is also generously fruitful, having around 5 to 8 fruit bunches, bearing about 5700 fruits per palm tree (CAVALCANTE 1996). Its fruits are rich in vitamin C, vitamin $\mathrm{A}$, carbohydrates and others.

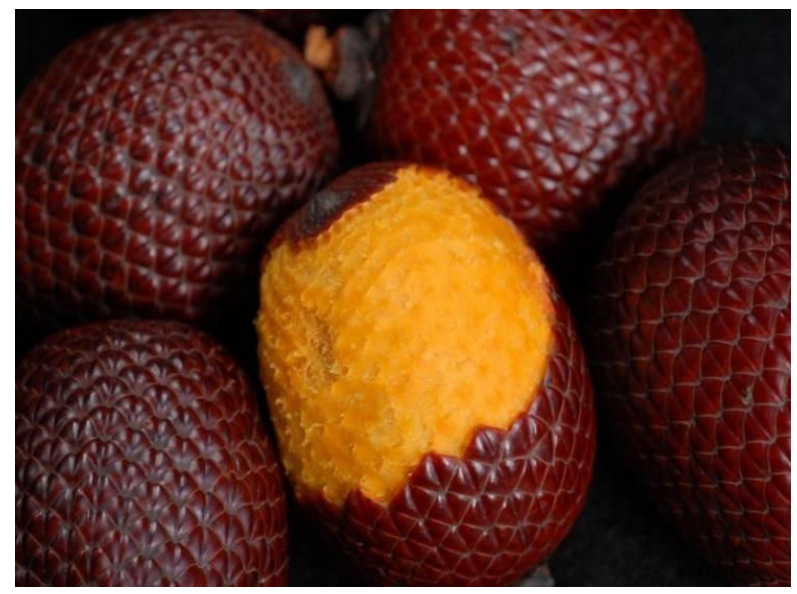

Figure 2: Miriti fruit

Source: http://comendocomosolhos.com/nove-frutas-everduras-exoticas/

This tree can provide people in innumerous ways. Regarding food, the tree can grant edible palm hearts and sugar; the pulp of the fruit can be eaten in its natural form or be used to make juice, fermented food, oil which can be ingested or used to frying - sweets, porridge or drank as a shake, similar to açaí, another Amazonian delicacy. Regarding its practical use, the tree can be used as a resource for handicraft, buildings, soap and others. The palm's leaves can be used for canopies; the fibers in the manufacture of rope, nets and mats. The trunks are also used as bridges in the margins of rivers or streams, in the entrance of the riverside houses and harbors. Additionally, they can be used to build rafts that help in transporting other kinds of wood (SANTOS; FERREIRA 2012).

The products made from the Mauritia flexuosa are used for trade or to supply the families' needs. For example, the "matapi", shown in figure 3 , is used by the riverside villagers to fish shrimps, which are one of the most common dishes from Abaetetuba city.

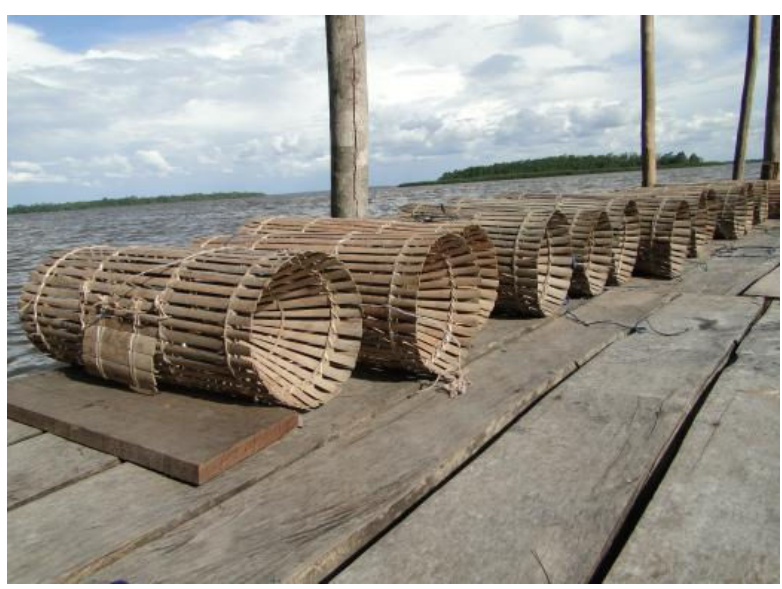

Figure 3: Matapi

Source: https://peabiru.org.br/2013/04/30/marajo-vivapesca-projeto-estimula-acordos-de-pesca-artesanal-emcurralinho/dsc07522/

According to the journal É do Pará from the online newspaper G1 Pará of October 2013, the adults formerly removed the fibers from the leaf's stalk to make sieves and trashed the leftover, the solid part. The kids from the place noticed that the disposed part could be carved into toys. Later the adults noticed the commercial value of it and started carving the toys.

The petiole of Miriti is composed of three parts, called by the handcrafters as: "tala", the most external part; peel and "bucha", the inner part, which is a soft and light material preferred to make the artisanal miriti toys.

These toys are the main objects build by the artisans from Abaetetuba city. It is a cultural heritage of the population, acknowledged by the inhabitants and by the state government, which officially value the objects (SANTOS; SILVA 2012).

So, the tradition of the mitiri toys is important to their manufacturers economically, acting as a finance resource to many families, as much as cultural, because "it rescues the memory and values that are vanishing from Abaetetuba, hence, should be valued and preserved" (LOBATO; PINHEIRO; RIBEIRO 2015: 343, own translation) ${ }^{1}$.

The miriti tree does not have to be brought down for the craft production. In an interview to the program "Sábados azuis", from TV Brasil, at 20 of October of 2011, the handcrafter Valdeli Costa from Abaetetuba said that, only half of the palm leaves are removed from the tree twice per year to be used as raw material for the crafts, respecting the time the plant requires to grow new leaves. According to Cavalcante (1996), each palm tree supports about 20 large leaves at its crown.

The artifacts made of miriti vary greatly, in both themes and sizes. The crafters make toys like boats, birds and dolls, also furniture, utensils and decoration items. They differ along with the will and creativity of the crafters and the demand of the clients. Some items are very colorful, others preserve their natural color;

\footnotetext{
${ }^{1}$ The original: "resgata a memória e os valores que estão desaparecendo de Abaetetuba, logo, precisa ser valorizada e mantida".
} 
others are articulated and interactive, nothing complex but always a thrive, especially in Belém during October. At this time occurs the biggest religious festival of the state and one of the biggest in the world, the Círio de Nazaré. Nonetheless, they are sold significantly around the world, mainly by the peculiarity of their material.

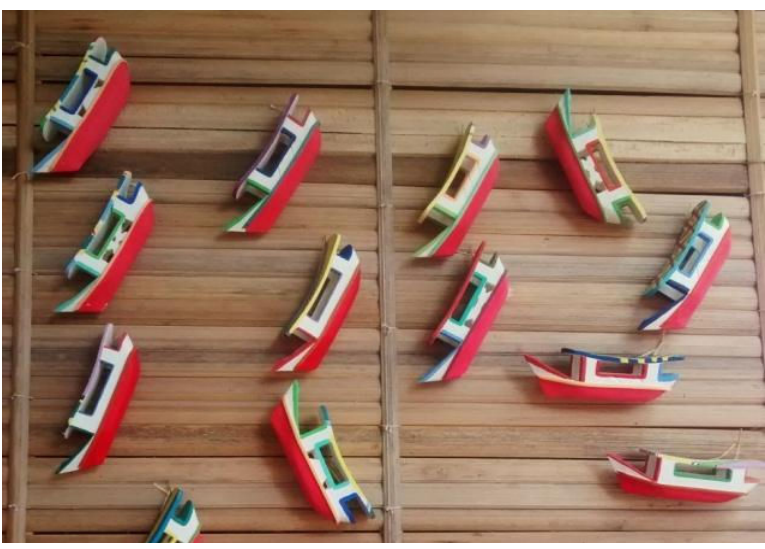

Figure 4: Mitiri boats.

Source: Authors' collection, 2016.

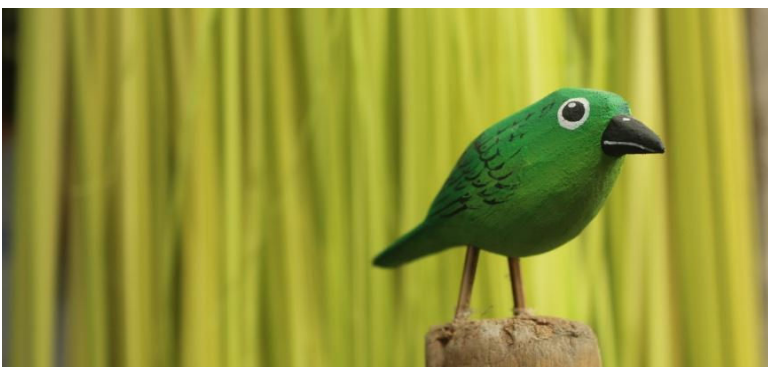

Figure 5: Miriti bird.

Source: Authors' collection, 2016.

The craft activity is generally hand down from parent to child and has a familiar production. The family members can split the tasks and work together to manufacture the products.

For the handcrafters, to do craftwork with miriti is a pleasuring practice, to which some refer metaphorically as "to play". The most important is that, out of this process, many can have a living.

The technician of the Brazilian Micro and Small Business Support Service (Sebrae), Adilson Rocha, who joined the same interview, mention that the miriti toys are an expression of the riverside population and that those toys represent all their perception and imagery.

Abaetetuba is the world capital of the miriti toy since this craft is broadly known around the world. The city itself has many monuments with this thematic. The town has a yearly festival, the MiritiFest. The event finished its 13 th edition in 2016 and it very important to promote the products derived from Mauritia as well as the tourism in the city.

\section{GOTAS: productions in culture and design}

Immersed in this territory, Design appears as an important ally for the development of society. The
GOTAS project, an extension project linked to the CUIA research group of the Design course of the University of Pará, proposed, in partnership with Miritong, an association of artisans from the municipality of Abaetetuba, under the responsibility of the artisan Valdeli Costa, to develop a collection of furniture inspired by the memories and daily life of the town. The purpose of the GOTAS project is to develop the territory through design productions with a focus on project management, new products elaboration by collective creation methodologies that direct products to market requirements; development of visual identity, management of production processes, improvement projects for equipment and work environments, and creation of mechanisms for relationship with the potential market.

The furniture creation workshop lasted three days, with the participation of three artisans, six design students and one teatcher that conducted the project. During the process there were also the participation of some photographers associated with Miritong.

To that end, the Niemeyer's (2003) methodology to develop the Visual Voice of the product was used to find the identity of the furniture collection and Krucken's (2009), which presents the three guidelines for designers towards the valorization of local products.

1. Promote the quality of products, territories, manufacturing processes;

2. Support communication, bringing together consumers and producers and intensifying territorial relations;

3. Support the development of productive arrangements and sustainable value chains, aiming to strengthen micro and small enterprises (KRUCKEN 2009:18, own translation $)^{2}$

With this, the immersion in the scenario process, in search for the identity of the collection, was initiated.

\subsection{Immersion in the scenario}

The immersion in the scenario pointed out the perceptions of the place that were recorded in a sensitive cartography $^{3}$ of Abaetetuba. From the five senses the components of GOTAS could see, hear, taste, smell and touch the place. "The sensitive cartography explored the senses of architecture, habitat, everyday scenes, the

\footnotetext{
${ }^{2}$ The original: " 1 . Promover a qualidade dos produtos, dos territórios, dos processos de fabricação; 2. Apoiar a comunicação, aproximando consumidores e produtores e intensificando as relações territoriais; 3. Apoiar o desenvolvimento de arranjos produtivos e cadeias de valor sustentáveis, visando ao fortalecimento de micro e pequenas empresas".

3 The sense of cartography used in the article is in accordance with Martin-Barbero's (2004) reflections, which dilutes the understanding of modern cartography as only representation of frontiers presenting it as a construction of images of the relations and interchanges of the ways.
} 
paths, the geocultural landscape, transport, in short, the life" (JARDIM et al. 2015:128, own translation) ${ }^{4}$.

This stage is extremely important both for creating a better relationship between the designer and the artisan as for the creative process of both. To Borges (2012) it is important to know the artisan-embroiderer and listen to her create ways to make emerge what she considers an icon.

With the teams divided by the five senses, first the urban part of the city of Abaetetuba was visited, covering the main roads of the city. The next day, a visit to the islands that are located around the city was made. With focus on each of the human senses, each component could live the scenario from different angles of perception of the place. In this process, some residents were interviewed, audiovisual records were made and some samples were collected. Thus, even in a short time, the daily life of the residents was experienced in an effective way, making it possible to immerse themselves in the ways of being and living in Abaetetuba. Everything is part of the geocultural landscape of the place.

The cartography points out that this cultural landscape is rooted in the life of these subjects, translating into an aesthetic of daily life that "[...] is organized by multiple facets of its process of life and transformation" (RICHTER 2003:21 apud JARDIM et al. 2015:130, own translation $)^{5}$.

With the immersion in the scenario, it is better to understand who these people are, "who seek in the aesthetic expression of their daily life, to free themselves and to show themselves to the other, marking their place, building their identity" (JARDIM et al. 2015:130, own translation) $)^{6}$.

\subsection{Collection's characterization}

The characteristics of the collection were identified according to the immersion in the scenario. This stage had the collective experience among the components of the project team based on the theoretical reference, the research on the municipality of Abaetetuba and the immersion in the scenario. The objective was to translate perceptions into thematic axes that communicated the essence of Abaetetuba, because, in Niemeyer's words, "[...] when we want to communicate something $[\ldots]$ we

\footnotetext{
${ }^{4}$ The original: "A cartografia sensível explorou os sentidos da arquitetura, do habitat, das cenas do cotidiano, os caminhos, a paisagem geocultural, os transportes, enfim, a vida"

${ }^{5}$ The original: "A cartografia aponta que aquela paisagem cultural está enraizada na vida desses sujeitos, traduzindo-se em uma estética do cotidiano que '[...] se organiza a partir de múltiplas facetas do seu processo de vida e de transformação"”.

${ }^{6}$ The original: "que buscam na expressão estética de sua cotidianidade, libertar-se e mostrar-se ao outro, marcando seu lugar, construindo sua identidade".
}

have to consider that this something already has a personality" (NIEMEYER 2007:64, own translation) ${ }^{7}$.

A brainstorming session was made, where each member listed words alluding the sensitive cartography from Abaetetuba. The starting point was the phrase "Between the river and the road", due the strong relationship between the inhabitants of the urban and rural city zones. According to Lucy Niemeyer (2009) orientations, the stages of the strategy consist of statements, relatively generic, which must be decomposed according to the brainstorming technique, during which the components are classified according to their importance for the total concept.

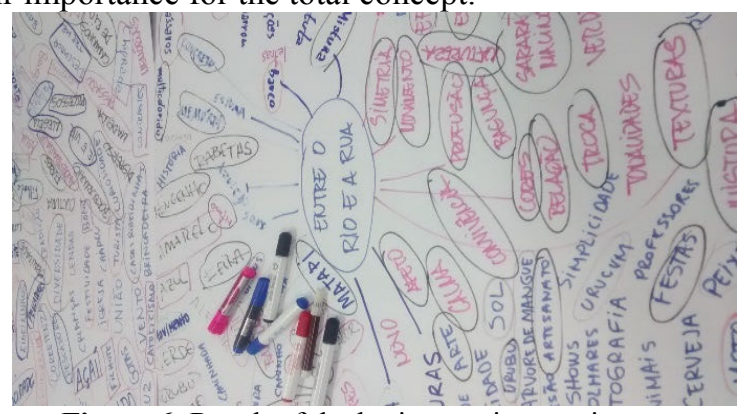

Figure 6: Result of the brainstorming session. Source: Authors' collection, 2016.

By the end of the brainstorming, "the selected terms will be analyzed and the team makes successive eliminations until they reach a number of three to four words that will be written in cards" (NIEMEYER, 2007:67, own translation) ${ }^{8}$. The words selected to summarize Abaetetuba's essence were: Between, River and Road. Between refers to

interrelationships, relations of dependence, mixtures, hybridizations between the self and the other, [...] local and global, zones of contact that are constituted in other places, which is no longer me or the other, but one between-place. (PRATT, 1999 apud JARDIM et al. 2015:126, own translation $)^{9}$

That led us to see affectivity, communion, encounters, dispute, exchanges, construction. River is the way, the come and go, movement, sinuosity. At last, road, represents the urban liveliness, profusion, forms, smells and sounds, the movement, a chaos that has its consistency, its symmetry, its composition.

Each concept raised three words that guided the choice of images to build concept panels and later the products' aesthetics, since "it is important to create a visual form that corresponds the aimed objective"

\footnotetext{
7 The original: "[...] quando se quer comunicar algo, [...] temos que considerar que este algo já tem uma personalidade".

${ }^{8}$ The original: "os termos selecionados serão analisados e a equipe faz sucessivas eliminações até chegar a uma síntese: três ou quatro palavras, que então serão escritas em cartões".

9 The original: "inter-relações, relações de dependência, misturas, hibridações entre o eu e o outro, [...] local e global, zonas de contato que se constituem em outros lugares, que não é mais nem eu, nem o outro, um entre-lugar."
} 
(BAXTER 2000:188, own translation) ${ }^{10}$. Thus, for the concept River the words were sinuous, breeze, come and go. For the concept Between, memory, movement and relationships. Lastly, for the concept Road, dynamic, profusion, and diversity.

Graphic 1: Collection's features

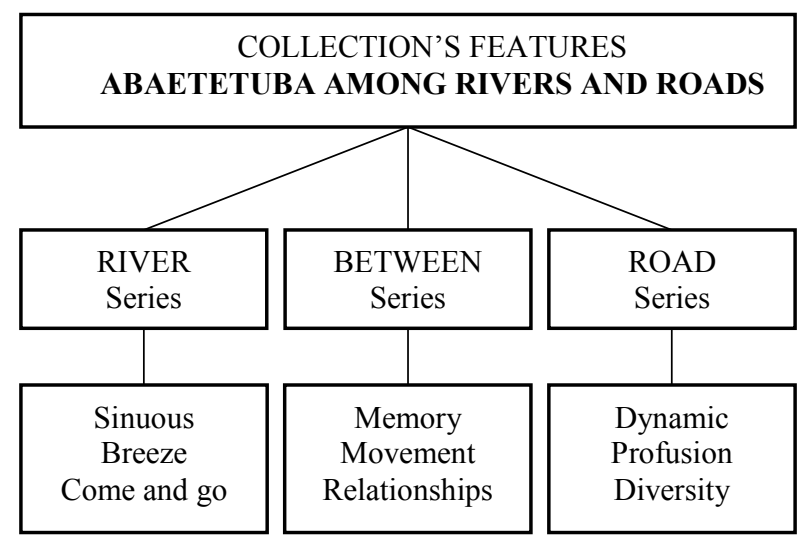

Following this, representative panels of the keywords were set, focusing in the colors, shapes and textures. Also other panels of products in the market that had the same concepts, which are images of products that fit the spirit of the new product. According to Baxter (2000), these styles represent a source of visual forms and inspiration for the new product. They can be tailored, combined or refined for the development of new product style.

Finally, the team gained many visual references that inspired the design of the furniture, as well as concepts to create the collection corresponding to Abaetetuba's identity. "With the synthesis at hand, the designer have marks to build a statement that 'voices' the product's personality, no matter its nature" (NIEMEYER 2007:68, own translation) $)^{11}$.

\subsection{Collective creation workshop}

The workshop included the presentation of the collection's concepts to the handcrafters, idea generation process, definition of the project and fabrication of the prototypes. The idea was to bring to the place of the workshop the atmosphere experienced during the immersion and to make the artisans identify with the concepts developed. Creating a sense of belonging is fundamental for the artisans to feel part of the process. For this reason, GOTAS uses collective creation as a methodology, where sketches are generated collectively among designers and artisans, in a process of exchange of knowledges and know-hows.

\footnotetext{
10 The original: "é importante criar uma forma visual do produto que reflita o objetivo pretendido"

${ }^{11}$ The original: "De posse da síntese feita, o designer tem um balizamento para a construção do enunciado a que se propõe, dando assim, a "voz" formal à personalidade do produto, seja ele de que natureza for".
}

For that, the posters and semantic panels made in the characterization stage of the collection were fixed so that the artisans understood the path that led to those concepts. With the panels, it was possible to identify patterns of colors, shapes and elements that translated the words chosen during the brainstorming, as well as presenting the artisans a new look at their daily life that could serve as inspiration for the pieces.

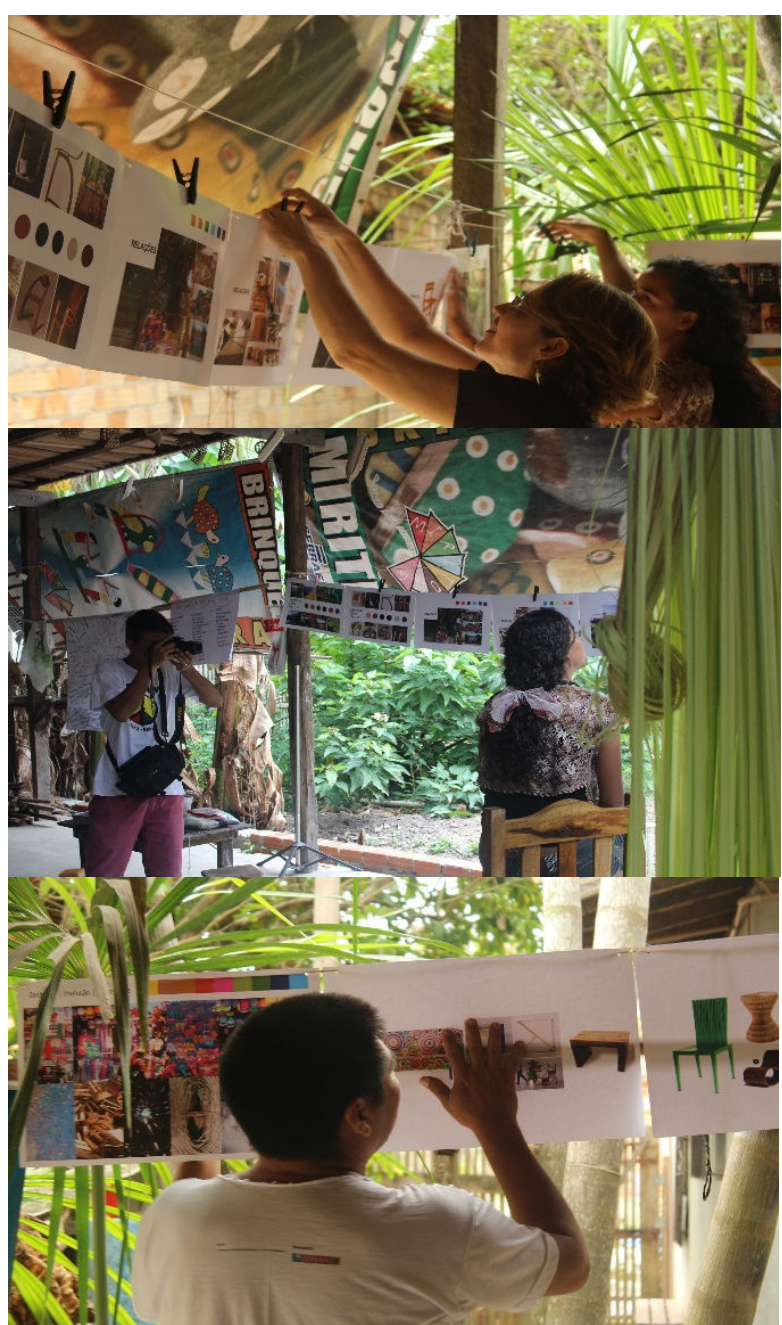

Figures 7: Presentation of collection concept. Source: Grupo Olhar Fotográfico, 2016.

The generation of ideas was composed by the free association of ideas and symbolic analogies, but the later tool was adapted. In the free association of ideas, there are a series of steps to follow to achieve what is wanted and these consist of Preparation, Incubation and Enlightenment. At the moment of preparation, it is collected the maximum amount of ideas and facts about what we want to design, done in moments of immersion and systematization. Incubation consists in the process of assimilation and processing of this information, done unconsciously by the brain, which finally results in enlightenment, where the idea that could be the solution of the problem in question arises. Whereas the symbolic analogy uses objective and impersonal images to describe the problem (BAXTER, 2000:69). These images build the panels made during the systematization. 
Each team member together with the artisans generated a series of finalized or underdeveloped sketches and shared them with the others, so that each member could identify positive and negative points in the pieces, propose changes, contributions and assess the feasibility of the given project. This way of sharing projects allowed greater collaboration and interlacement between participants and the creation of a larger number of feasible projects.

As the sketches were being adjusted and finalized, they were presented to the artisans to start making the prototypes.
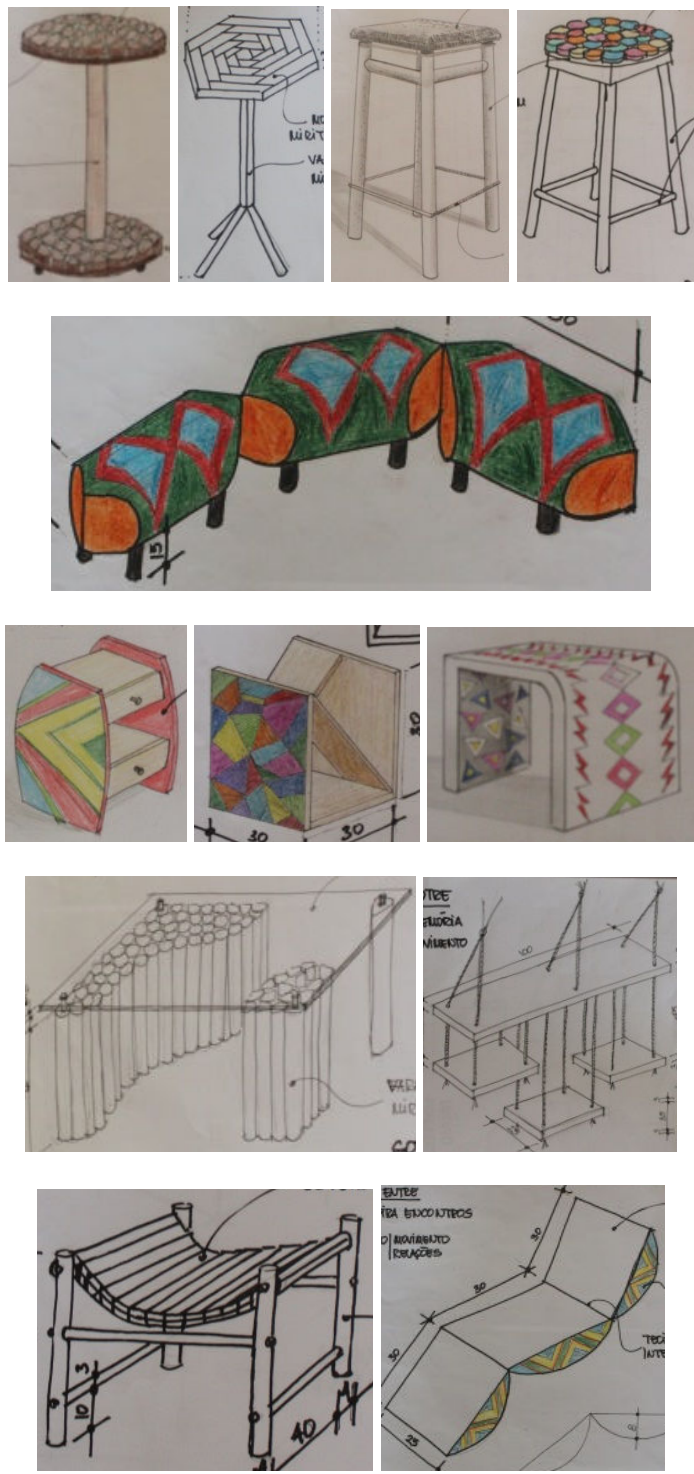

Figure 8: Sketches created.

Source: Authors' collection, 2016.

The collection "Abaetetuba between Rivers and Roads" was defined with four products per series.

River series: Maresia bench, Fluxos table, nightstand Ribeirinho, table Ilhas.
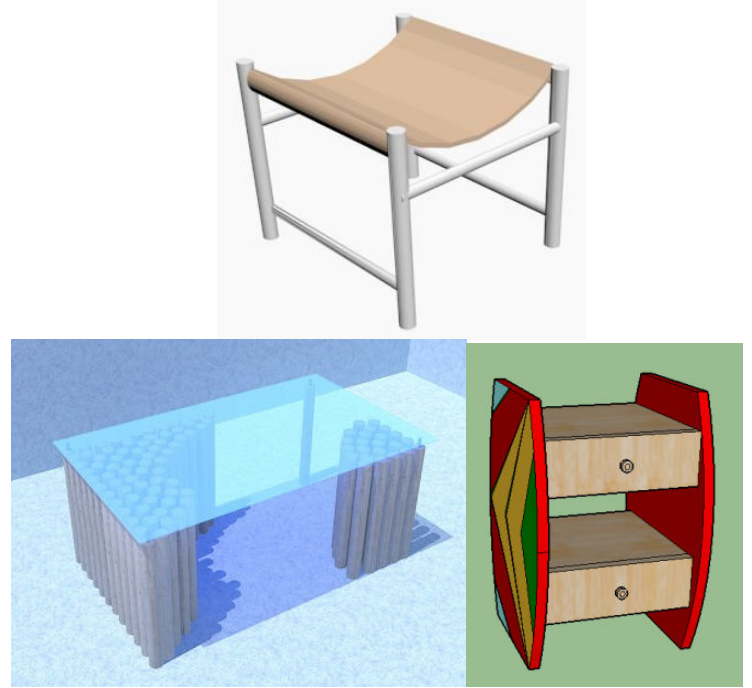

Figure 8: Furniture from River series Source: Authors' collection, 2016.

Between series: support Entrelaces, bench Boiúna, shelf Encontros and stool Maurítia.
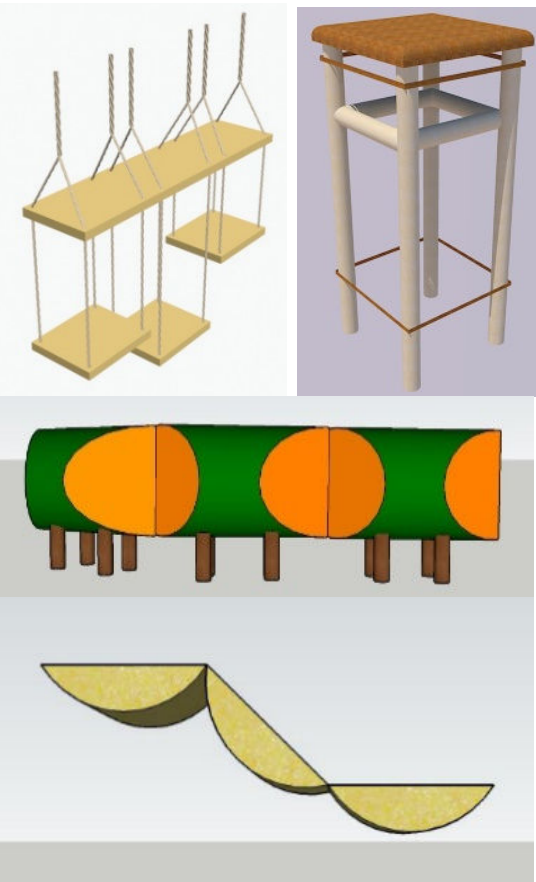

Figures 9: Furniture from Between series

Source: Authors' collection, 2016.

Road series: module Fragmentos, bench Batidão, stool Profusão and Tauerá coffee table.
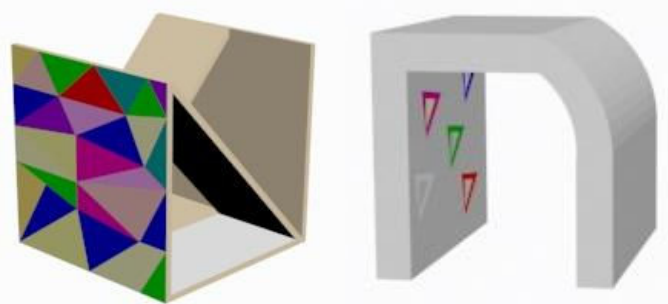


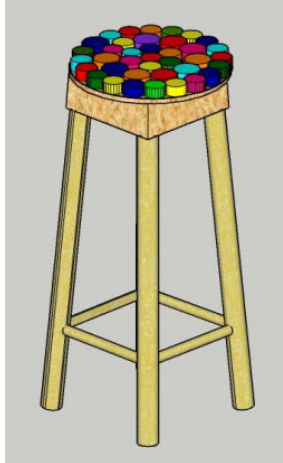

Figuras 10: Furniture from Road series.

Source: Authors' collection, 2016.

Most of the items have low to medium complexity and can be made with the basic tools from the craftsmen themselves. Thus, the production process becomes much more agile and simplified, giving more independence of production to the one that will make them.

For some pieces, the experimentation of another material to compose the aesthetics of the product, such as the polyester resin, was planned. Due to the absence of resin in the artisan community for experimentation, the components to be tested with the material were brought to the University and will be tested. If the results are positive, there will be a future workshop for the artisans about the polymer and its ways of being worked on.

During the workshop it was possible to construct some furniture components and two prototypes. The pieces built were those of the table Ilhas, which will undergo resin tests, the Profusão stool and the braided seat from Maurítia stool. Among the prototypes made were the shelf Encontros and the table Tauerá.

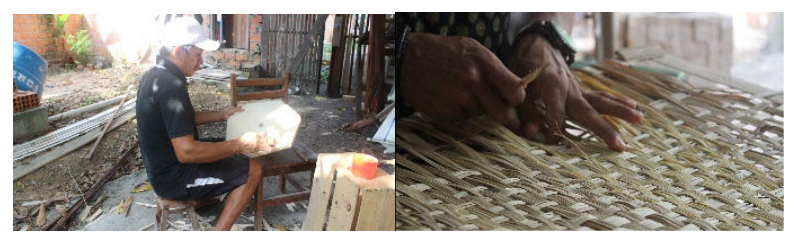

Figures 11: Manufacture of parts and prototypes.

Source: Authors' collection, 2016.

\section{Conclusion}

The results obtained after completing the planning, immersion, synthesizing and workshop stages are able to translate very clearly the daily life of Abaetetuba, its stories and its imaginary, and become a material record of the peculiarities of that people.

For artisans, knowing new production techniques, creation and the possibility of developing new products, provides bigger creative freedom and re-signification of their products without losing traces of their tradition, thus promoting better reach in the consumer market and, consequently, generating higher income for livelihood and self-sufficiency of the community.

For academics, there was a real practice of all the knowledge learned within the classroom, and the ability to adapt methodologies and ideas to the reality of that context, as well as to learn techniques from the knowhow of those people.

For the Gotas Project, this second work done with artisan communities can maintain the satisfactory result obtained in other editions, which generates motivation to follow the valorization of local products through the design.

This partnership between designers and artisans can highlight the possibility of uniting academic knowledge with traditional know-how, without any disrespect for the other, in a sum of knowledge and improvement of techniques not found if the contexts were isolated.

\section{References}

BORGES, A. Design + Artesanato: o caminho brasileiro. São Paulo: Editora Terceiro Nome, 2012.

BAXTER, M. Projeto de Produto. São Paulo: Blucher, $2^{\mathrm{a}}$ edição, 2000.

CAVALCANTE, P. B. Frutas comestiveis da Amazônia. Belém: CNPq/ Museu Paraense Emílio Goeldi,1996. (coleção Adolpho Ducke)

JARDIM, N.R et al. Projeto Gotas: Uma experiência interdisciplinar em design e artesanato. In: Simpósio de Design Sustentável, 5. 2015, Rio de Janeiro, 2015. Artigo... Rio de Janeiro, Simpósio de Design Sustentável.p,121 - 133 .

KRUCKEN, L. Design e território: valorização de identidades e produtos locais. Studio Nobel: São Paulo, 2009.

LOBATO, L.; PINHEIRO, D.; RIBEIRO, J.. A tradição do brinquedo de miriti no currículo das escolas do município de Abaetetuba: iniciando o debate. Revista Margens, Abaetetuba - PA, v. 9, n. 12, p. 341-359, $2015 . \quad$ Disponível em: $<$ http://periodicos.ufpa.br/index.php/revistamargens/artic le/viewFile/3093/3113> Acesso em: 16 dez 2016.

NIEMEYER, L. Elementos de semiótica aplicados ao design, $2^{\mathrm{a}}$ edição. Rio de Janeiro: 2AB, 2007.

PESCE, Celestino. Oleaginosas da Amazonia. Belém: Revista da Veterinaria, 1941.

SHANLEY, P.; MEDINA, G.. Frutiferas e Plantas Úteis na Vida Amazônica. Belém: CIFOR, Imazon, 2005.

SANTOS, I.; SILVA, M.F. Saberes da tradição nos brinquedos de miriti - patrimônio cultural. Revista Educação, Cultura e Sociedade, Sinop - MT, v. 2, n. 2, p. 63-77, 2012. Disponível em: $<$ http://sinop.unemat.br/projetos/revista/index.php/educa cao/article/view/673/704> Acesso em: 18 dez 2016.

SANTOS, R.; FERREIRA, M. Online: $<$ http://www.scielo.br/scielo.php?script=sci_arttext\&pid $=$ S0044-59672012000100001 $>$. Acesso em dez. 2016.

Tv Brasil. Miritong - Associação Arte Miriti Sábados Azuis. Disponível em: $<$ https://www.youtube.com/watch?v=Xh8n6jUKw7Y $>$. Acesso em 17 dez 2016.

É do Pará. Pará. Semanal. Disponível em: $<$ http://g1.globo.com/pa/para/e-dopara/noticia/2015/05/tradicao-do-miriti-se-reinventa- 
pelas-maos-de-artesaos-de-abaetetuba.html>. Acesso em 18 dez. 2016.

É do Pará. Pará. Semanal. Disponível em: $<$ http://g1.globo.com/pa/para/noticia/2013/10/artesanatode-miriti-encanta-paraenses-e-turistas.html $>$. Acesso em 19 dez. 2016.
Instituto Brasileiro de Geografia e Estatística IBGE. Abaetetuba. Disponível em: $<$ http://cidades.ibge.gov.br/xtras/perfil.php?lang=\&codm un $=150010 \&$ search=para|abaetetuba|infograficos:informacoes-completas> Acesso em: $11 \mathrm{dez} 2016$. 